\title{
Percolation pond as a method of managed aquifer recharge in a coastal saline aquifer: A case study on the criteria for site selection and its impacts
}

\author{
Raicy Mani Christy and Elango Lakshmanan* \\ Department of Geology, Anna University, Chennai 600 025, India. \\ *Corresponding author.e-mail: elango34@hotmail.com
}

MS received 16 August 2016; revised 2 February 2017; accepted 16 February 2017; published online 17 July 2017

Percolation ponds have become very popular methods of managed aquifer recharge due to their low cost, ease of construction and the participation and assistance of community. The objective of this study is to assess the feasibility of a percolation pond in a saline aquifer, north of Chennai, Tamil Nadu, India, to improve the storage and quality of groundwater. Electrical resistivity and ground penetrating radar methods were used to understand the subsurface conditions of the area. From these investigations, a suitable location was chosen and a percolation pond was constructed. The quality and quantity of groundwater of the nearby area has improved due to the recharge from the pond. This study indicated that a simple excavation without providing support for the slope and paving of the bunds helped to improve the groundwater quality. This method can be easily adoptable by farmers who can have a small pond within their farm to collect and store the rainwater. The cost of water recharged from this pond works out to be about $0.225 \mathrm{Re} / \mathrm{l}$. Cleaning the pond by scrapping the accumulated sediments needs to be done once a year. Due to the small dimension and high saline groundwater, considerable improvement in quality at greater depths could not be achieved. However, ponds of larger size with recharge shafts can directly recharge the aquifer and help to improve the quality of water at greater depths.

Keywords. Seawater intrusion; ground penetrating radar; electrical resistivity method; groundwater quality; recharge well/shaft; Chennai.

\section{Introduction}

Depletion of groundwater resources has become a major issue in several regions of the world over the last few decades. Groundwater depletion has been reported as a severe hydrogeologic threat in major parts of North Africa, East, South and Central Asia, North China, North America and Australia as well as in several other parts of the world (Konikow and Kendy 2005). Climate change and large scale abstraction of groundwater for irrigation purposes has also accelerated the problem of groundwater depletion (Hertig and Glesson 2012). Large scale abstraction lead to groundwater depletion which affects the sustainability of water supplies (Schwartz and Ibaraki 2011), land subsidence, reduction in surface water flows, spring discharges and well yields, lose of wetlands (Bartolino and Cunningham 2003; Konikow and Kendy 2005), rise in pumping costs and sea water intrusion (Huntington 2008).

The large-scale implementation of managed aquifer recharge (MAR) schemes at carefully selected sites to enhance the groundwater storage 
will help to overcome the problem of groundwater depletion. The efficiency of MAR schemes depends a lot on the hydrogeological conditions and the quality of water used for recharge. Selection of suitable sites for the implementation of MAR structures needs to be carried out carefully with extensive hydrological, hydrogeological and engineering investigations as the efficacy of these structures depends on site-specific conditions (Chowdhury et al. 2010; Russo et al. 2014). MAR has been successfully implemented to mitigate seawater intrusion in many parts of the world. A treated sewage recharge scheme in Salalah coastal aquifer, Oman (Shammas and jacks 2008), percolation pond in Korba coastal plain, Tunisia (Paniconi et al. 2001), in Queensland, Australia (Werner 2001) in Pondicherry, India (Sundaram et al. 2008), check dams in Chennai, India (Parimala and Elango 2013) were implemented. Groundwater modelling was also used to understand the effect of recharge structures by some researchers (Mohammadi 2008; Rostami et al. 2010; Hashemi et al. 2013).

According to CGWB (2005), about $14 \%$ of the area of India is suitable for aquifer recharge. Construction of check dams and percolation ponds as MAR schemes as part of watershed management projects has been widely practiced in India with the support of the Indian Government as well as other international agencies (Farrington et al. 1995). Percolation ponds have become very popular methods of MAR due to their low cost, ease of construction and the participation and assistance of community. The benefit of one such percolation pond as a method of MAR, north of Chennai was investigated as a part of this study. The objective of this study is to assess the feasibility of a percolation pond in a saline aquifer, north of Chennai, Tamil Nadu, India, to improve the storage and quality of groundwater.

\section{Methodology}

\subsection{Description of the study area}

The study area forms a part of Arani river basin located about $40 \mathrm{~km}$ north of Chennai, Tamil $\mathrm{Nadu}$, India (figure 1). The area lies nearly $3.8 \mathrm{~km}$ west of Bay of Bengal and $0.15 \mathrm{~km}$ east of Arani river, which joins the sea at about $4 \mathrm{~km}$ north through Pulicat estuary. The atmospheric temperature in this area varies from $22^{\circ} \mathrm{C}$ to $43^{\circ} \mathrm{C}$.
The average annual rainfall in the area is about $1200 \mathrm{~mm}$. The Arani river is non-perennial and flows for short periods during the north-east monsoon (October-December). However, during nonmonsoon periods, when the river is not flowing, saline water from the estuary enters into the river up to a distance of about $4 \mathrm{~km}$. Buckingham Canal, generally carrying saline water, runs parallel to the coast near the eastern boundary. This canal always contains water, as its base is at about $-2.0 \mathrm{~m} \mathrm{msl}$ and is connected to the Bay of Bengal through the rivers that cut across the canal.

Topographically, the study area is generally flat and there is no considerable variation in elevation. The elevation of the study area is $3 \mathrm{~m}$ msl. The important geomorphic units in the area include alluvial and coastal plains. The seismic refraction survey carried out at the Arani Korattalair river basin by Dwarakanath et al. (1968) confirms different lithologic layers in the area. The basement of this region comprises of gneissic and charnockite rocks of Proterozoic era which is overlain by Gondwana and Tertiary formations (UNDP 1987). Quaternary formation, consisting of clay, silt, sand and gravel and their admixtures and also sandstone of about 45-60 m thickness occupies the top of the sequence, which are underlined by carbonaceous shales of Upper Gondwana. The thick alluvial sediments indicate that the sedimentation in the area might have started sometime during Holocene marine transgression. The transgression must have naturally given rise to changes in base levels of the rivers which resulted in the accumulation of alluvial sediments along river valleys, shifting of river courses, and development of coastal plains. The Holocene marine transgression with oscillations after last glaciations carried the sea to its present level within the range of radiocarbon dating (20,000 years) (Bird 1969). The deposition of Quaternary sediments in the alluvial plains of Arani river is attributed to riverine and marine activities (Rao 1979). The very high salinity of groundwater along the coastal region of this area is attributed to the presence of marine deposits of Holocene age (Rao 1979). Excessive pumping of groundwater from the site during the last few decades has also led to seawater intrusion (Elango and Manickam 1987; UNDP 1987; Elango and Ramachandran 1991; Charalambous and Garratte 2011; Raicy et al. 2014; Rajaveni et al. 2015). The quaternary formation functions as an unconfined aquifer. The groundwater occurs at shallow depth. The depth 


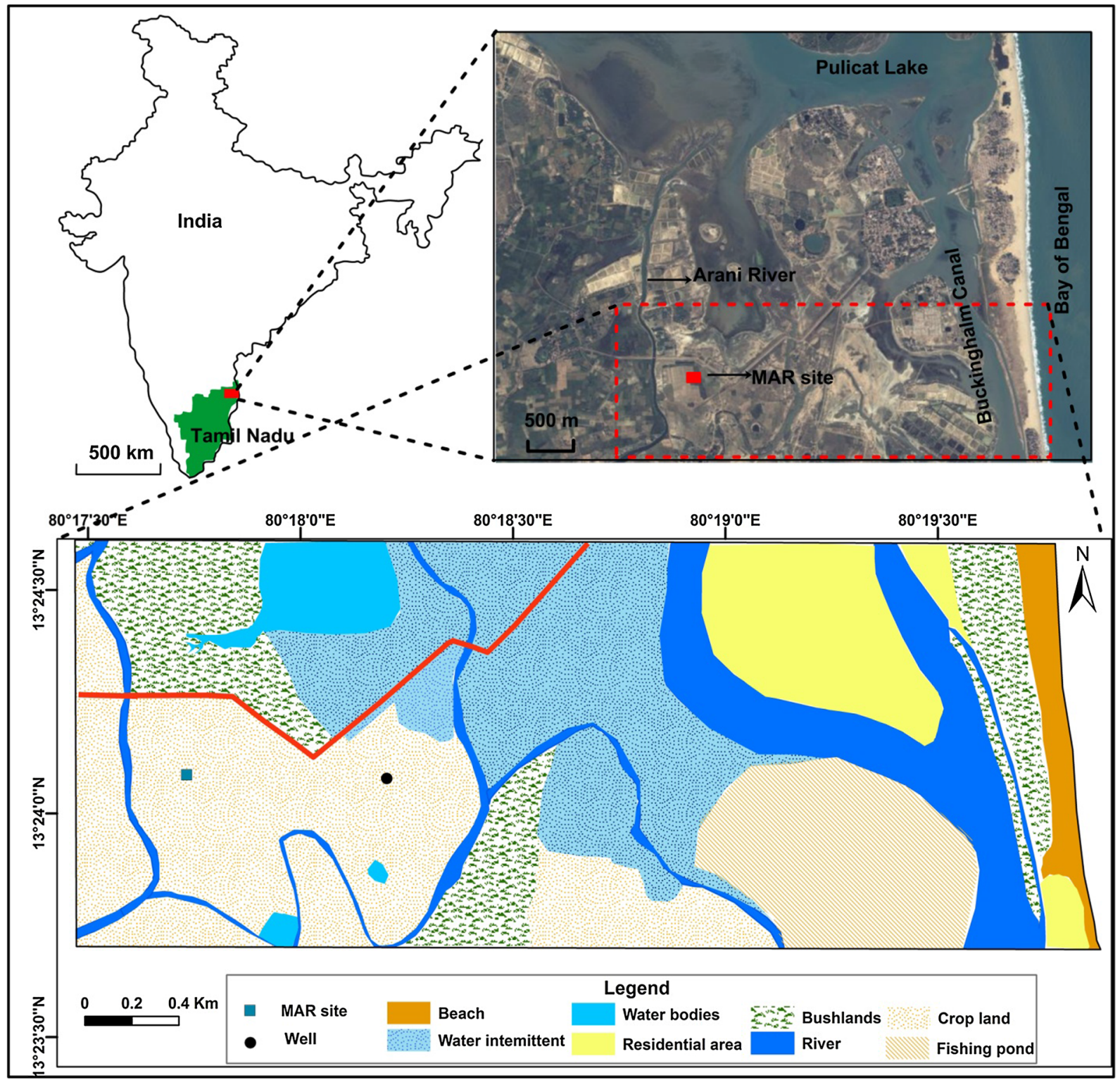

Figure 1. Location of the study area showing major morphological characteristics.

to groundwater table varies from 2 to $3 \mathrm{~m}$ from ground surface. The groundwater flow direction is from west to east.

\subsection{Field investigation methods}

Extensive field investigations were carried out in the study area by means of a resistivity meter and a ground penetrating radar in order to select suitable location for the construction of percolation pond. Electrical resistivity survey was carried out in the study area to understand the subsurface characteristics. This method is advantageous as it can be carried out rapidly and is relatively inexpensive (Choudhury et al. 2001; Calvache et al. 2011). Electrical direct current is applied between the two current electrodes rooted in the ground and the electrical potential between two other electrodes is measured in this method. The qualitative comparison of observed responses of apparent resistivity with standard theoretical resistivity values helps to detect bodies of anomalous materials beneath the surface of the earth. The vertical variations in the geological formations of the study area were understood from the electrical signatures obtained by vertical electrical sounding (VES) using a resistivity meter (ABEM SAS 1000). Schlumberger method of electrode arrangement was adopted during the resistivity survey. The maximum spacing between current electrodes were from 66 to $86 \mathrm{~m}$. VES was carried out at six locations in and around the study site (figure 2). 


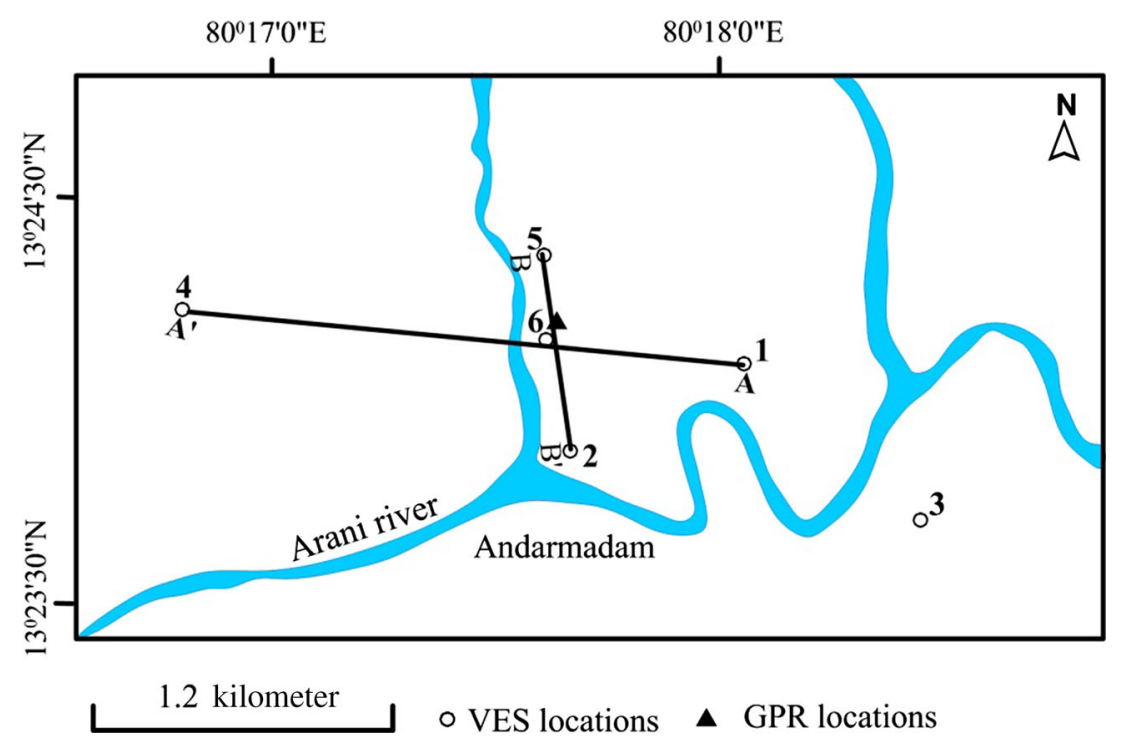

Figure 2. The locations of VES survey and GPR survey in the study area.

The thickness of subsurface layers at these sites was determined by an inverse modeling method using IX1D v2 (IX1D 2008) software. Inverse modelling was carried out to match with the resistivity curve obtained from the field survey with the theoritical curves.

Ground penetrating radar (GPR), a high resolution tool, is increasingly used to investigate the nature of sediments and the environment of deposition of sediments (Deshraj et al. 2012). GPR (Pulse EKKO PRO 100) with a $50 \mathrm{MHz}$ bistatic antenna having a resolution of $0.5 \mathrm{~m}$ was used to understand the stratification beneath the surface. The basis of interpretation of GPR records is the behaviour of electromagnetic waves, which depends on the magnetic permeability, dielectric constant and electrical conductivity of the sedimentary units and the GPR system-antenna characteristics (Daniels et al. 1988). Radar energy is reflected at boundaries of electrically dissimilar materials where there is a contrast in the dielectric properties. These boundaries typically occur at stratigraphic discontinuities, but may occur at the water table and within stratigraphic units where changes in electrical properties occur. When the GPR antenna is pulled across the surface, a continuous profile record is generated and displayed as a two-way travel time $v s$. distance plot on a console for immediate evaluation. Data were collected by line mode and the depth of penetration of electromagnetic radiations was about $20 \mathrm{~m}$. In this method, as the radar amplitudes or attenuations are influenced by both dielectric constant and the electrical conductivity of the medium, subsurface variations can be investigated. This survey was carried out over a profile of length of about $150 \mathrm{~m}$. The radargram was processed using EKKO_View V2 (EKKO_View 2008) software. Both electrical resistivity and GPR survey helped to broadly understand the subsurface lithology of the study region and based on these investigations, a suitable location was selected for the construction of percolation pond.

\subsection{Construction of percolation pond}

A percolation pond was constructed at VES location 6 during May 2012. An approximate slope of $45^{\circ}$ was maintained for the sides of the pond. Since the purpose of the study is to assess the feasibility of a simple and low cost structure, which can be followed by several farmers, the size of the pond was chosen as $8 \times 8 \times 1.75 \mathrm{~m}$. A wired fence was erected at a distance of $2.5 \mathrm{~m}$ around the pond to prevent unauthorized entry of people and to keep the instruments safe. Three piezometers, namely, $\mathrm{P}_{1}$, $\mathrm{P}_{2}$ and $\mathrm{P}_{3}$ with diameter of $0.2 \mathrm{~m}$ each, distance of separation of $0.5 \mathrm{~m}$ and respective depths of 2,4 and $6 \mathrm{~m}$ were constructed during July 2012 by hand augers near the eastern margin of the pond and were cased with PVC pipes with their bottom slotted for a length of $0.5 \mathrm{~m}$. The slotted $(3 \times 75 \mathrm{~mm})$ portion of the casing in the piezometers were also wrapped with plastic mesh to prevent the entry of finer material and the annular space outside the mesh was filled with coarse sand. The bottom of the pipes was also covered with plastic mesh. Provision was made to keep the boreholes closed with a lid at 


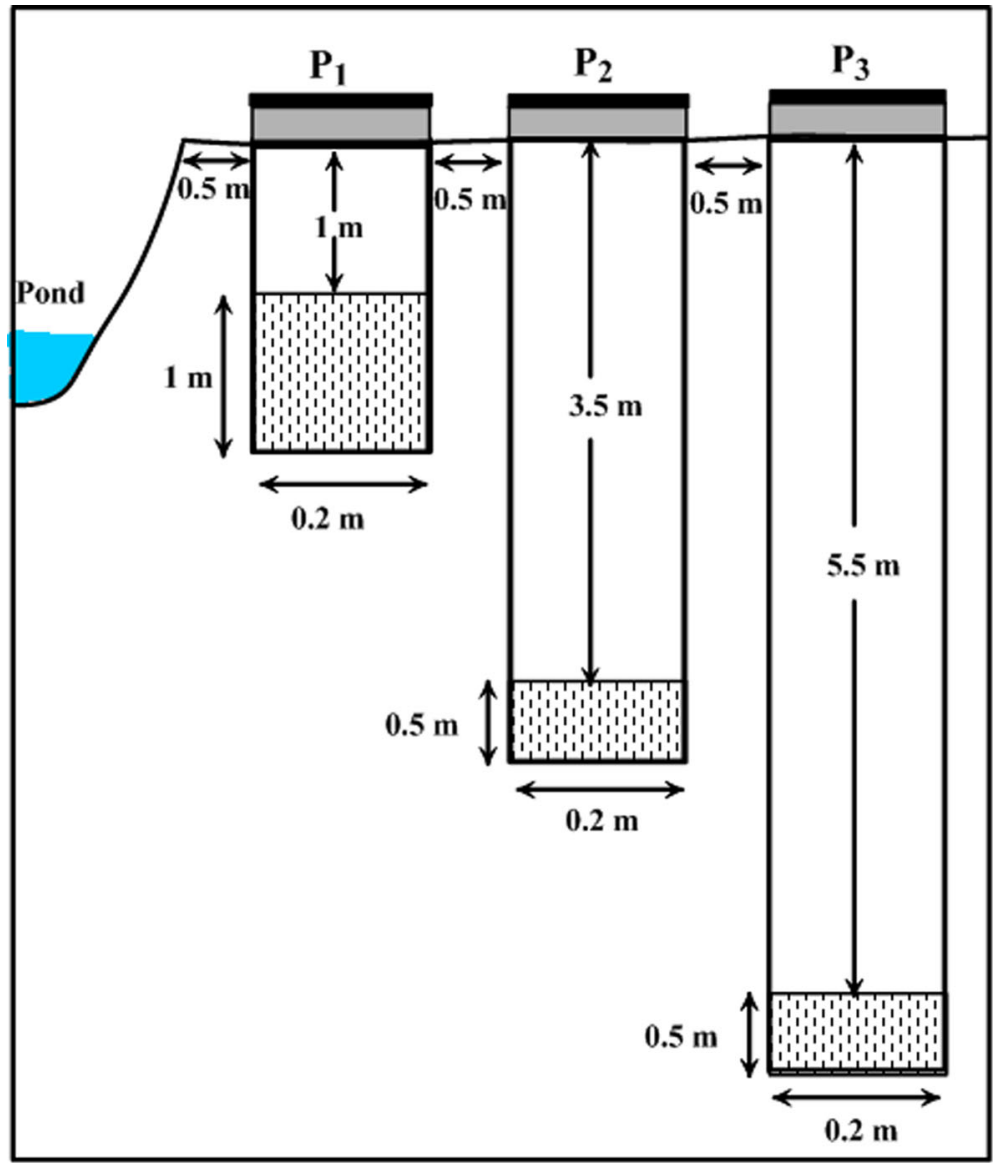

Figure 3. Schematic design of the piezometers constructed near the percolation pond.

the top. A schematic diagram showing piezometers is shown in figure 3 .

\subsection{Field and laboratory measurements}

Rainfall in the area was monitored every 6 hrs by means of an automatic weather station, installed on the roof of a $5 \mathrm{~m}$ tall building at an approximate distance of $100 \mathrm{~m}$ from the pond. Digital automatic water level recorders (Solinst 3001) were installed in piezometers and were set to monitor the groundwater level every $3 \mathrm{~min}$. The water level and electrical conductivity of water measured in an open well (figure 1) nearly $0.9 \mathrm{~km}$ away from the percolation pond reported by Nair (2016) was also used in this study. Water samples from the pond and the three piezometers were collected in clean, inert $500 \mathrm{ml}$ plastic bottles every two weeks. The alkalinity of water samples was measured by titration (Merck 1.11109.0001) and the electrical conductivity was measured using a conductivity meter (Eutech Cyber scan 600) immediately after the collection in the field itself. A default temperature of $25^{\circ} \mathrm{C}$ and a linear temperature coefficient of $2.1 \%$ per ${ }^{\circ} \mathrm{C}$ were selected in the conductivity meter to directly measure temperature corrected EC. The total dissolved solids (TDS) in water were estimated by multiplying EC with 0.64 (epa.gov). Samples were filtered with $0.22 \mu \mathrm{m}$ filter paper and were analysed after suitable dilution. The water samples were brought to the laboratory immediately after collection and were analysed for the concentration of major and minor ions by an ion chromatograph (Metrohm Compact 861).

\section{Results and discussion}

\subsection{Subsurface investigation}

\subsubsection{Vertical electrical sounding (VES)}

VES data were interpreted by an automotive deteriorative process of interpretation in which the computer code performs the necessary adjustment to a layered model derived by an approximate interpretation method in order to improve the correspondence between observed and calculated functions (Kearey et al. 2002). The true resistivity values obtained by inverse modelling of the data 
Table 1. The VES model details of different layers in the study area.

\begin{tabular}{|c|c|c|c|c|c|c|}
\hline $\begin{array}{l}\text { Site } \\
\text { no. }\end{array}$ & $\begin{array}{l}\text { Depth } \\
(\mathrm{m})\end{array}$ & $\begin{array}{l}\text { Minimum } \\
\text { resistivity } \\
\text { (ohm-m) }\end{array}$ & $\begin{array}{l}\text { Maximum } \\
\text { resistivity } \\
\text { (ohm-m) }\end{array}$ & $\begin{array}{l}\text { Type of } \\
\text { curve }\end{array}$ & $\begin{array}{c}\text { Layer } \\
\text { thickness }(\mathrm{m})\end{array}$ & $\begin{array}{l}\text { True resistivity } \\
\text { (ohm-m) }\end{array}$ \\
\hline 1 & 41 & 2 & 160 & $\mathrm{Q}$ & $\begin{array}{l}0-3 \\
3-10 \\
10-41\end{array}$ & $\begin{array}{l}160-15 \\
15-5 \\
5-2\end{array}$ \\
\hline 2 & 44 & 0.3 & 1200 & $\mathrm{Q}$ & $\begin{array}{l}0-3 \\
3-10 \\
10-44\end{array}$ & $\begin{array}{l}12000-150 \\
150-13 \\
13-0.3\end{array}$ \\
\hline 3 & 44 & 5 & 1100 & $\mathrm{Q}$ & $\begin{array}{l}0-3 \\
3-10 \\
10-44\end{array}$ & $\begin{array}{l}1100-180 \\
180-80 \\
80-5\end{array}$ \\
\hline 4 & 40 & 5 & $1.3 \times 10^{4}$ & Q & $\begin{array}{l}0-3 \\
3-10 \\
10-40\end{array}$ & $\begin{array}{l}1.3 \times 10^{4}-3 \times 10^{3} \\
3 \times 10^{3}-250 \\
250-5\end{array}$ \\
\hline 5 & 44 & 3.5 & 300 & $\mathrm{H}$ & $\begin{array}{l}0-9 \\
9-44\end{array}$ & $\begin{array}{l}300-10 \\
10-22\end{array}$ \\
\hline 6 & 31 & 4 & 1100 & $\mathrm{H}$ & $\begin{array}{l}0-1 \\
1-4 \\
4-5.2 \\
5.2-31\end{array}$ & $\begin{array}{l}>1100 \\
1100-90 \\
90-25 \\
25-22\end{array}$ \\
\hline
\end{tabular}

obtained by VES are summarised in table 1 . The apparent resistivity curves obtained at different locations are shown in figure 4. Two types of resistivity curves were obtained from VES survey carried out in the study area and they are ' $Q$ ' and ' $\mathrm{H}$ ' types. Locations 1, 2, 3 and 4 correspond to ' $Q$ ' type of curves and locations 5 and 6 correspond to ' $\mathrm{H}$ ' type of curves. Locations 1, 2, 3 and 4 generally displays smoothly sloping curves in the upper reaches reflecting high resistivity values followed by low resistivity values near the surface. The VES curves at locations 5 and 6 are characterized by a pronounced concave shape reflecting high resistivity values at the shallow surface that decreases with depth and then increases slightly.

Locations 1, 2, 3 and 4 have three layers each, among which the top layer extends up to about $3 \mathrm{~m}$, followed by second layer, which extends up to nearly $10 \mathrm{~m}$ and the third layer continues after that. Location 5 is characterized by a very low resistivity and has two layers, in which top layer extends up to a depth of approximately $9 \mathrm{~m}$. Location 6 is characterized by four layers, in which the top two layers extend up to depths of 1.2 and $4 \mathrm{~m}$ respectively, which is followed by a thin lens of low resistivity layer of $1.2 \mathrm{~m}$ thickness. In general, the resistivity values of these layers are comparatively low due to the presence of the saline groundwater.
Two resistivity cross sections $\mathrm{AA}^{\prime}$ and $\mathrm{BB}^{\prime}$ were drawn connecting locations $5,6,2$ and 4 , 6, 1 respectively using the true resistivity values obtained from inverse modelling (figure 5 ). The former is along west-east direction and the latter is along north-south direction. The resistivity values decrease from 11,000 to $13,000 \mathrm{ohm}-\mathrm{m}$ to below $10 \mathrm{ohm} \mathrm{m}$ with respect to depth in both the cross sections. The resistivity values abruptly decrease after a depth of about $2 \mathrm{~m}$. The very low resistivity below an approximate depth of $2 \mathrm{~m}$ is attributed to the high salinity of groundwater. In cross section $\mathrm{AA}^{\prime}$ and $\mathrm{BB}^{\prime}$ (figure 5), the resistivity increases from west to east and south to north respectively. This is probably attributed to increase in saline water influx from the Arani river.

Out of the six locations, in which the VES was carried out, at location 6 , the resistivity values increase beyond the electrode spacing of $20 \mathrm{~m}$ (figure 4). Even though the site is located not more than $1 \mathrm{~km}$ from location 5 , the resistivity values increase probably due to the presence of coarser materials at depth.

The interpreted lithology by inverse modelling of the resistivity data of location 6 is shown in figure 6. By comparing the range of true resistivity values of each layer with standard resistivity values of different lithological units (Kaufman and Hoekstra 2001), layers 1, 2, 3 and 4 are interpreted 

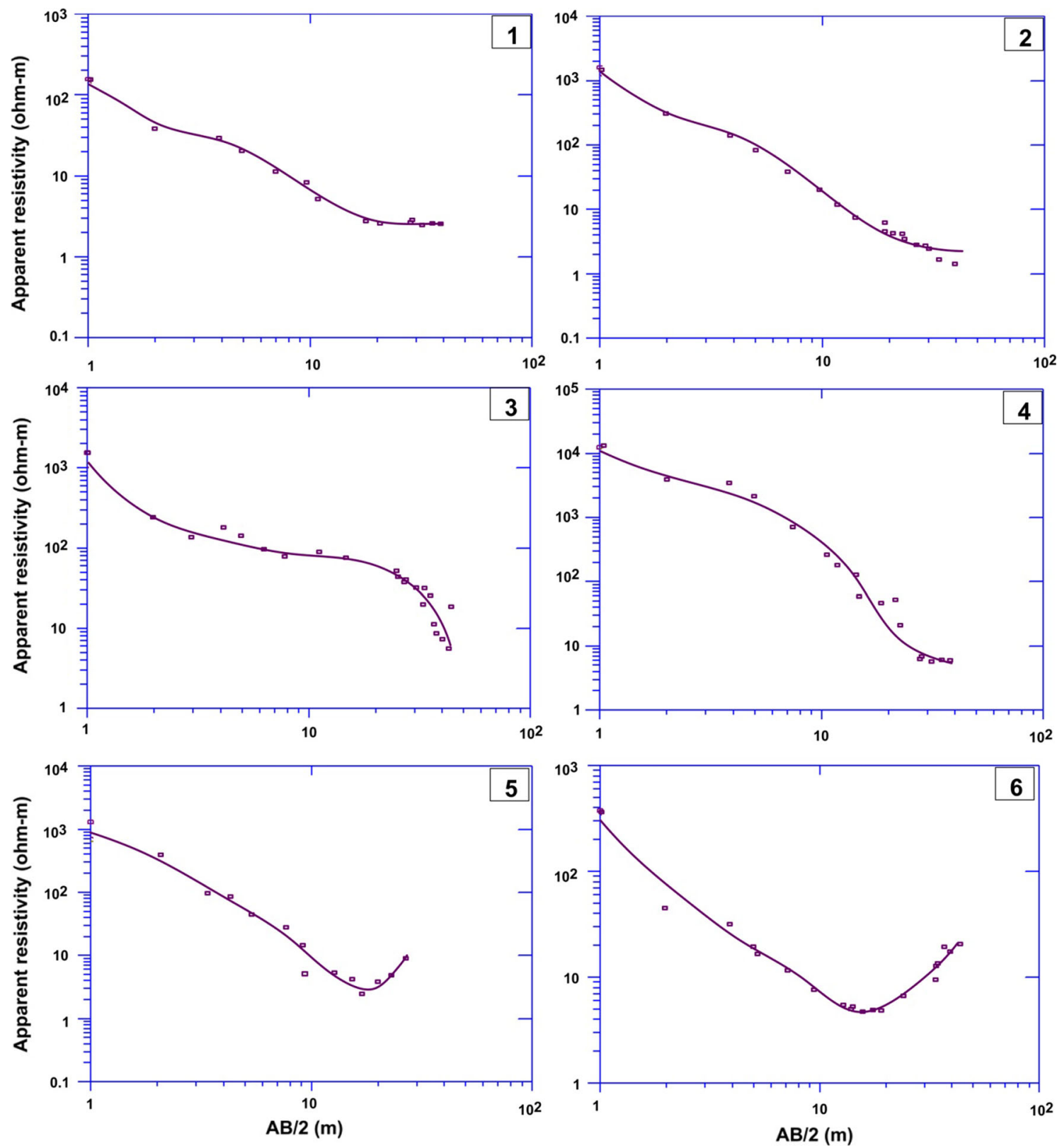

Figure 4. Apparent resistivity curves of locations 1, 2, 3, 4, 5 and 6 ( $\mathrm{AB}=$ current electrode spacing).

as sandy silt, silty sand, silt and sand respectively (figure 6). The top layer extends up to a depth of $1.2 \mathrm{~m}$ which is underlined by silty sand layer up to a depth of $4 \mathrm{~m}$. As the ground surface consists of sandy silt up to a depth of about $1.5 \mathrm{~m}$, percolation of rain water through this layer will be less. However, this site was selected for the construction of percolation pond since this site is likely to have coarser sediments beyond the depth of $10 \mathrm{~m}$. Hence, this site was chosen for the construction of percolation pond of depth of $2 \mathrm{~m}$, so that the comparatively permeable silty sand is exposed at the bottom of the pond. To investigate the lithologic variation at more fine resolution, just beneath the proposed location of the pond, GPR technique was also used.

\subsubsection{Ground penetrating radar (GPR)}

The radargrams obtained from the GPR survey were processed and were interpreted to understand the subsurface signatures in the area. A wiggle plot was generated from the radargram (figure $7 \mathrm{a}$ ) to illustrate the variation in subsurface amplitude of signals with respect to position and time. This plot shows traces in overlapping vertical columns with no deflection or deflection to the left or right, representing zero, positive and negative amplitudes 

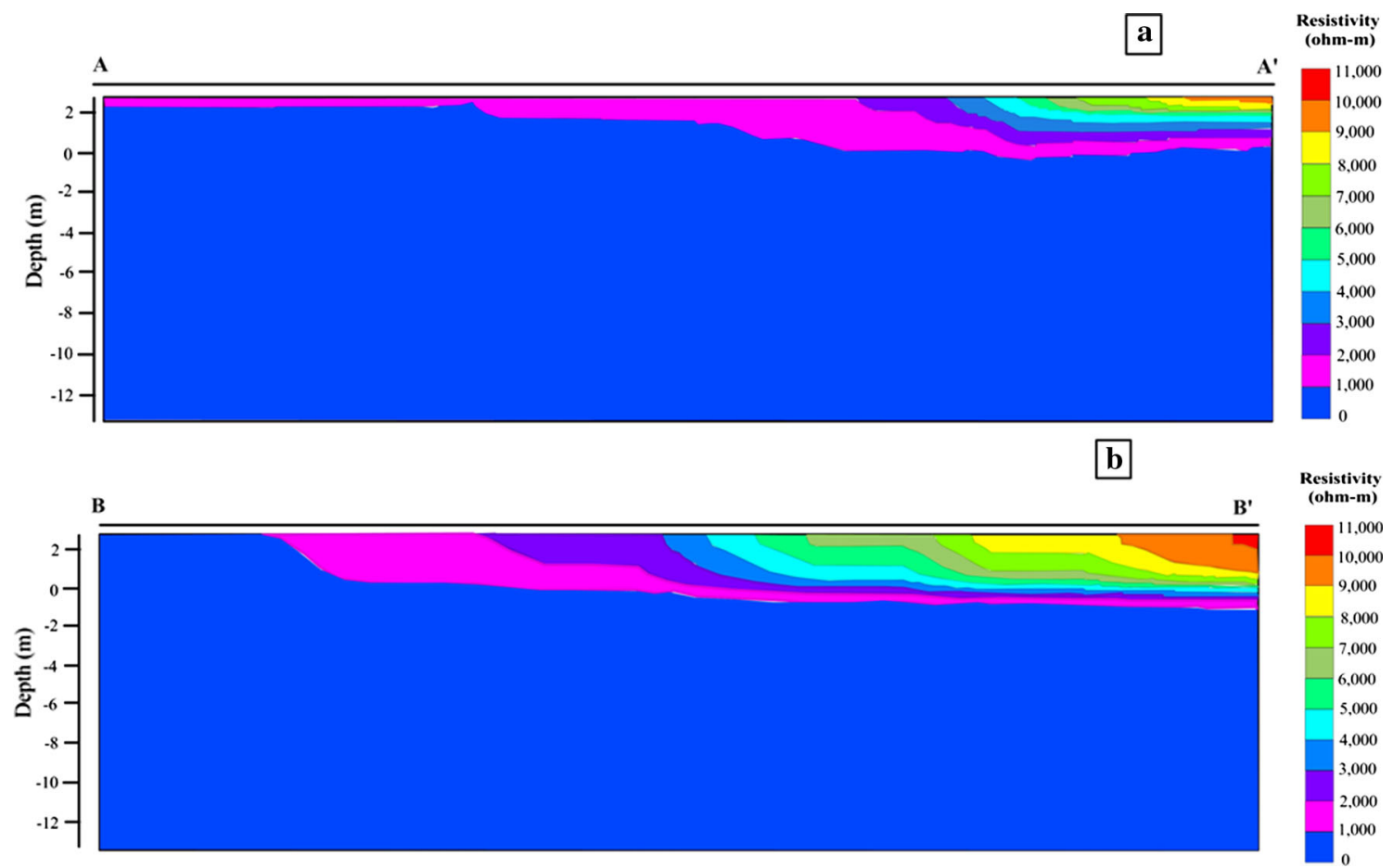

Figure 5. (a) The east-west and (b) north-south two dimensional cross sections of subsurface resistivity of the study area.
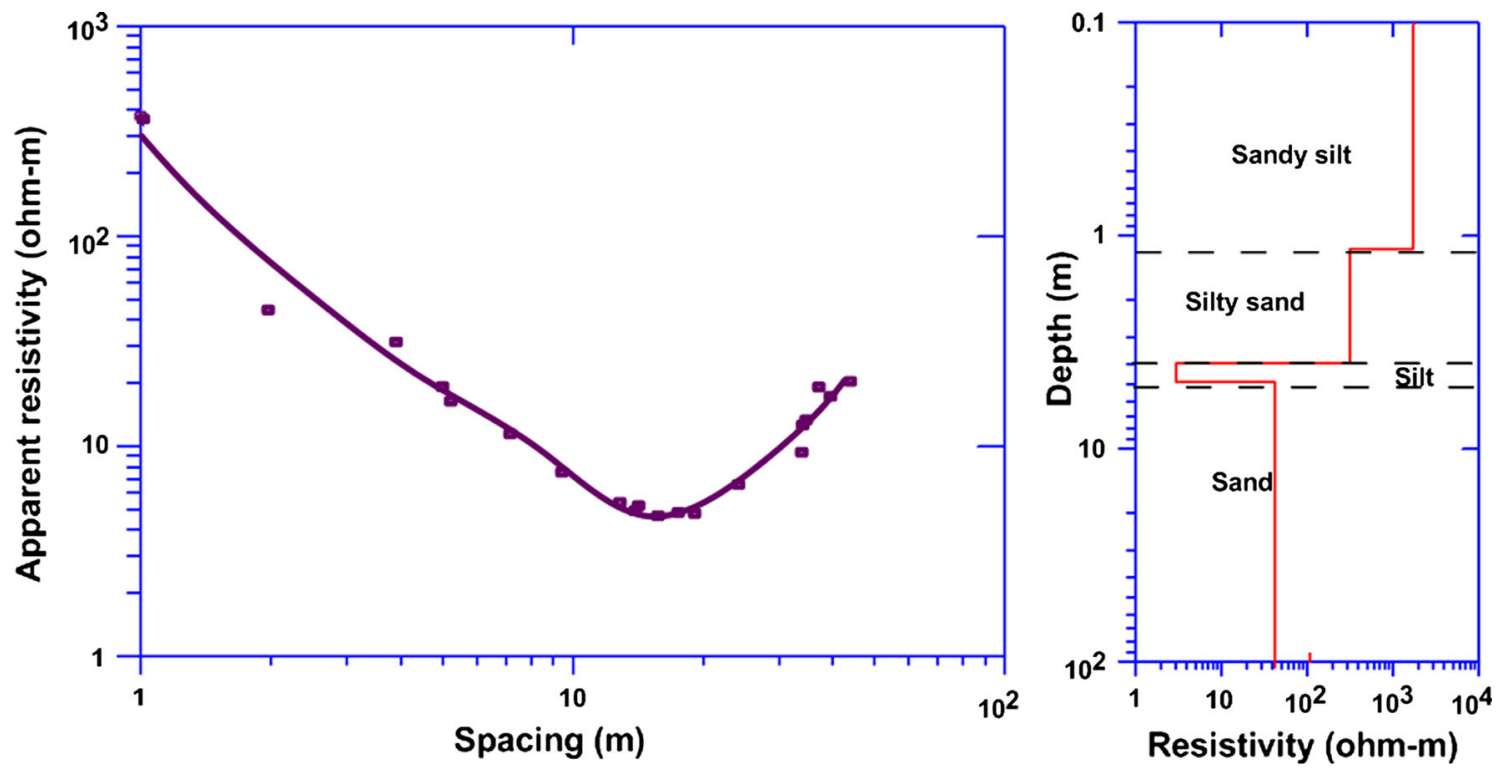

Figure 6. Resistivity curves and interpreted lithology after inverse modeling.

respectively. The amplitude of GPR signatures in the radargram varies over depth depending on the soil texture and spatial variation in soil moisture (Western et al. 1998). The processed radargram is shown in figure 7(b) and the inferred subsurface layers are shown in figure 7 (c). As a result of high velocity and high attenuation of radar energy, the first to return are air waves which are followed by ground waves. Thus, the top layer in figure 7(c) represents air waves and the next are due to ground waves. In layers 1 and 2 , shown in figure $7(\mathrm{c})$, the wavelengths of electromagnetic signals are high up to a depth of about $5.5 \mathrm{~m}$. Horizontal and continuous signatures occur up to a depth of nearly $4.5 \mathrm{~m}$ in layers 1 and 2 .

Highly saline groundwater in the saturated zone causes a decrease in wavelength and an increase in amplitude. Layer 3 is characterized by discontinuous signals indicating saline water. However, the reflection patterns obtained at this site are not 

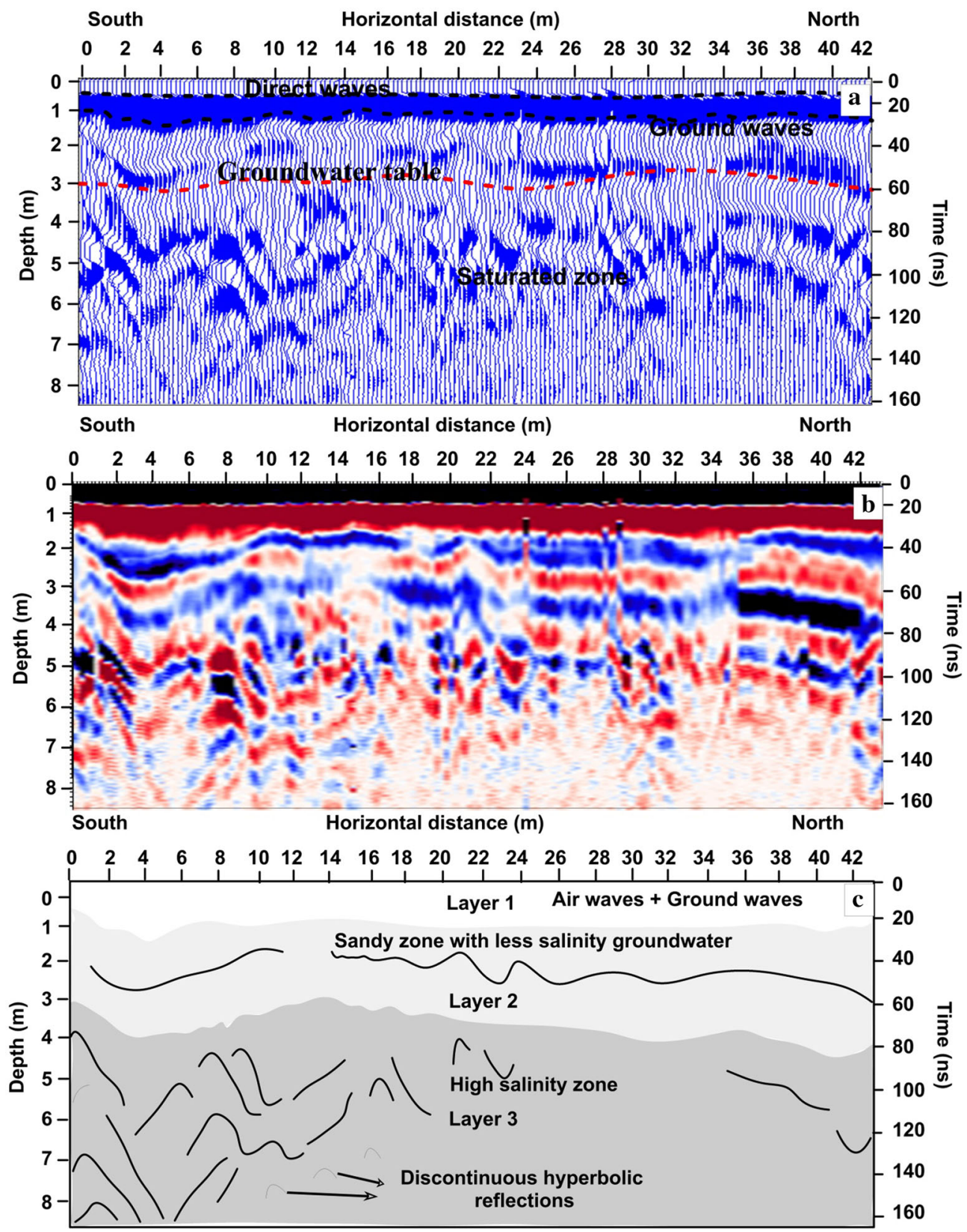

Figure 7. (a) Vertical variation in amplitudes of GPR signatures in a wiggle trace plot, (b) GPR radargram, and (c) interpreted lithology.

unique and similar patterns could be arising from sediments deposited in various environments. For example, hummocky discontinuous reflections are interpreted as accretionary spit beach sand and gravel by Van et al. (1998) as vegetated sand dunes by Bristow et al. (2000), as poorly resolved sets of trough cross stratification by Bristow (2000) and as beach ridge deposits by Neal and Roberts (2000).

The depth to groundwater table in the area was measured as $3 \mathrm{~m}$, while drilling of the piezometer, which is in accordance with the inference made from the GPR. The VES and GPR indicated that the surface formations in the area are characterized by less permeable layers. Fine sand is present at a depth of about $1.2 \mathrm{~m}$ from the ground surface and hence the depth of the pond was decided as $1.5 \mathrm{~m}$.

\subsection{Improvement in groundwater level}

The percolation pond was constructed at the site of VES location 6 during May 2012. The pond started filling with run-off water during the middle of September, after the commencement of northeast monsoon. Water level in the pond rose to 


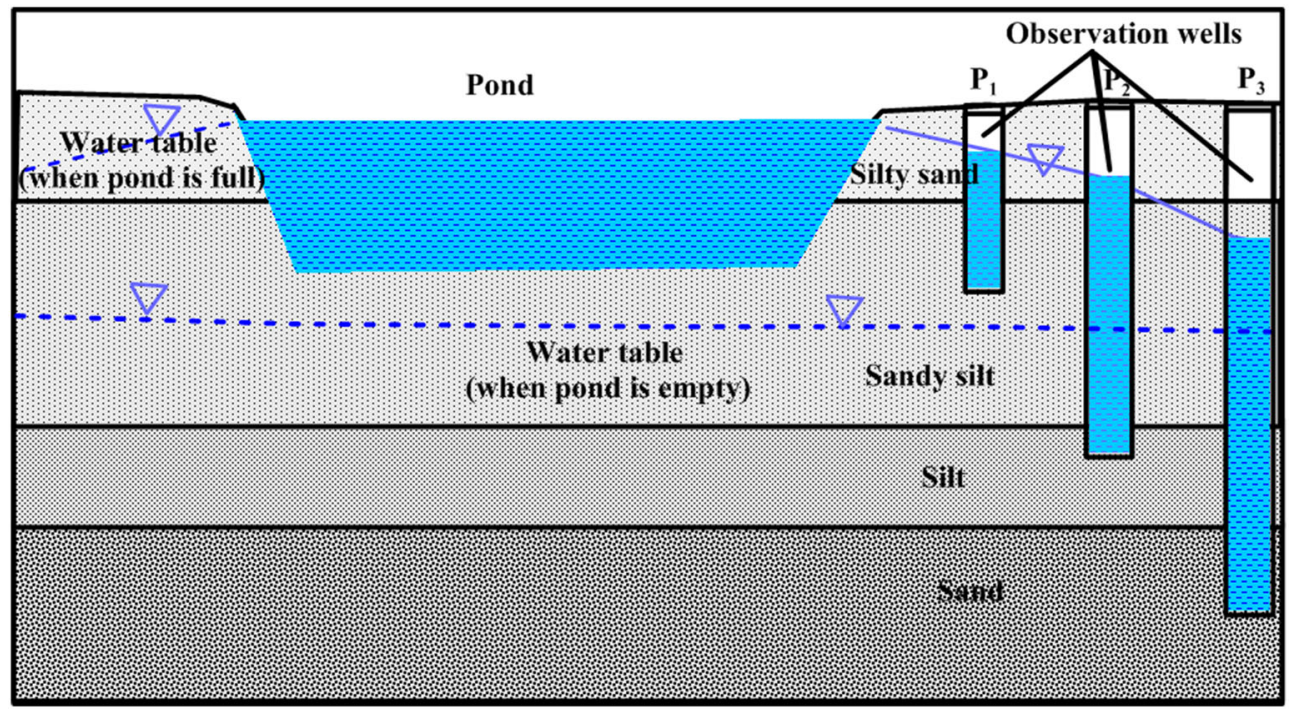

Figure 8. Conceptual cross section along west-east direction across the pond and piezometers.

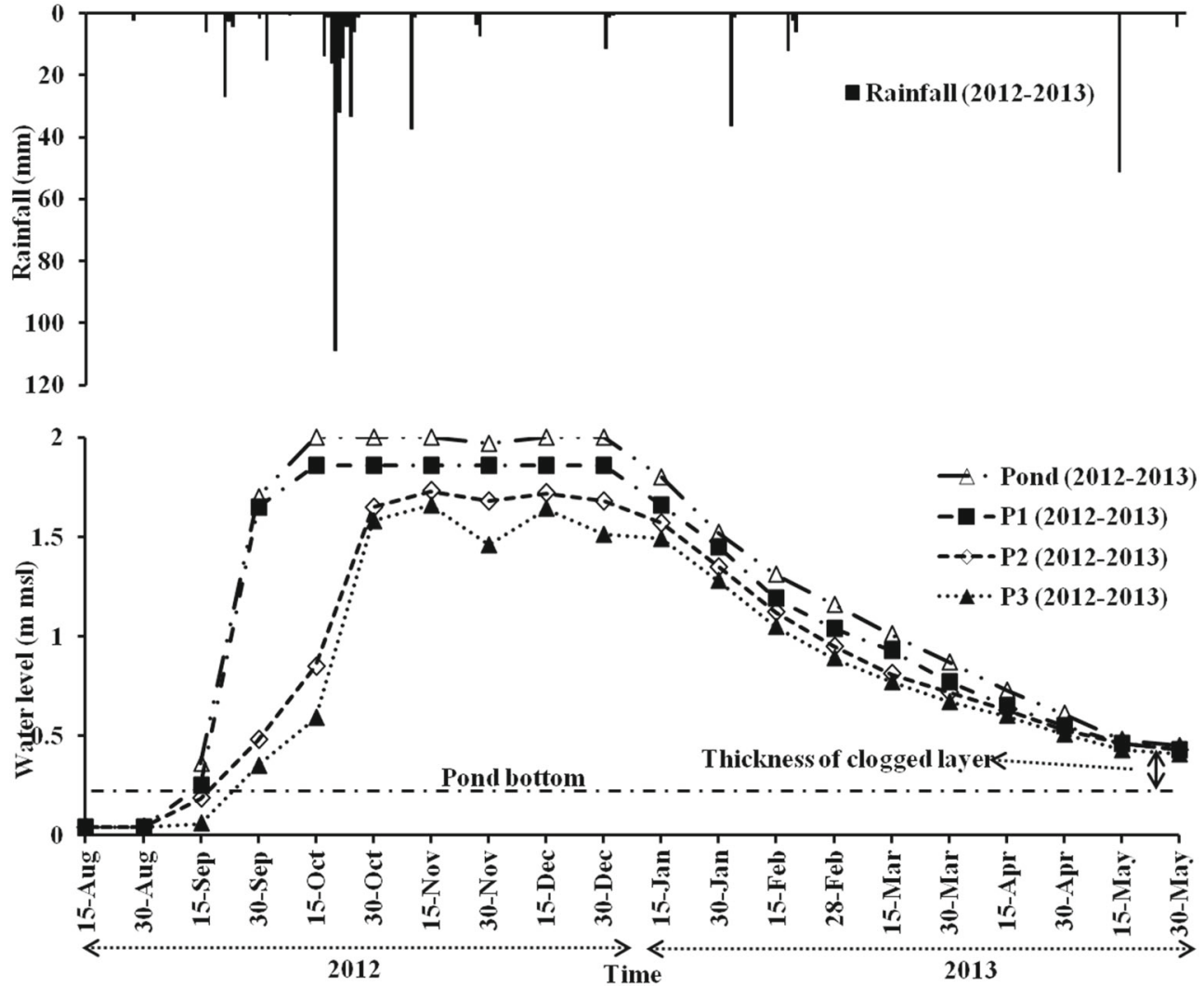

Figure 9. Temporal variation in rainfall and the water level in the pond and piezometers.

its maximum level by the end of September. The water level in the piezometers rose with respect to the rise in water level in the pond in such a way that the depth to water level in piezometers were increasing with the distance from the pond. This indicates that the depth to water level was very shallow in the piezometer $\left(\mathrm{P}_{1}\right)$ located close to the pond as compared to $\mathrm{P}_{2}$ and $\mathrm{P}_{3}$, which are 1 and $1.5 \mathrm{~m}$ respectively away from the pond. Figure 8 shows the conceptual cross section along west-east direction of the area with water level in pond and piezometers. In this figure, the water level on the right side of the pond is based on the water level measurements in the piezometers, 

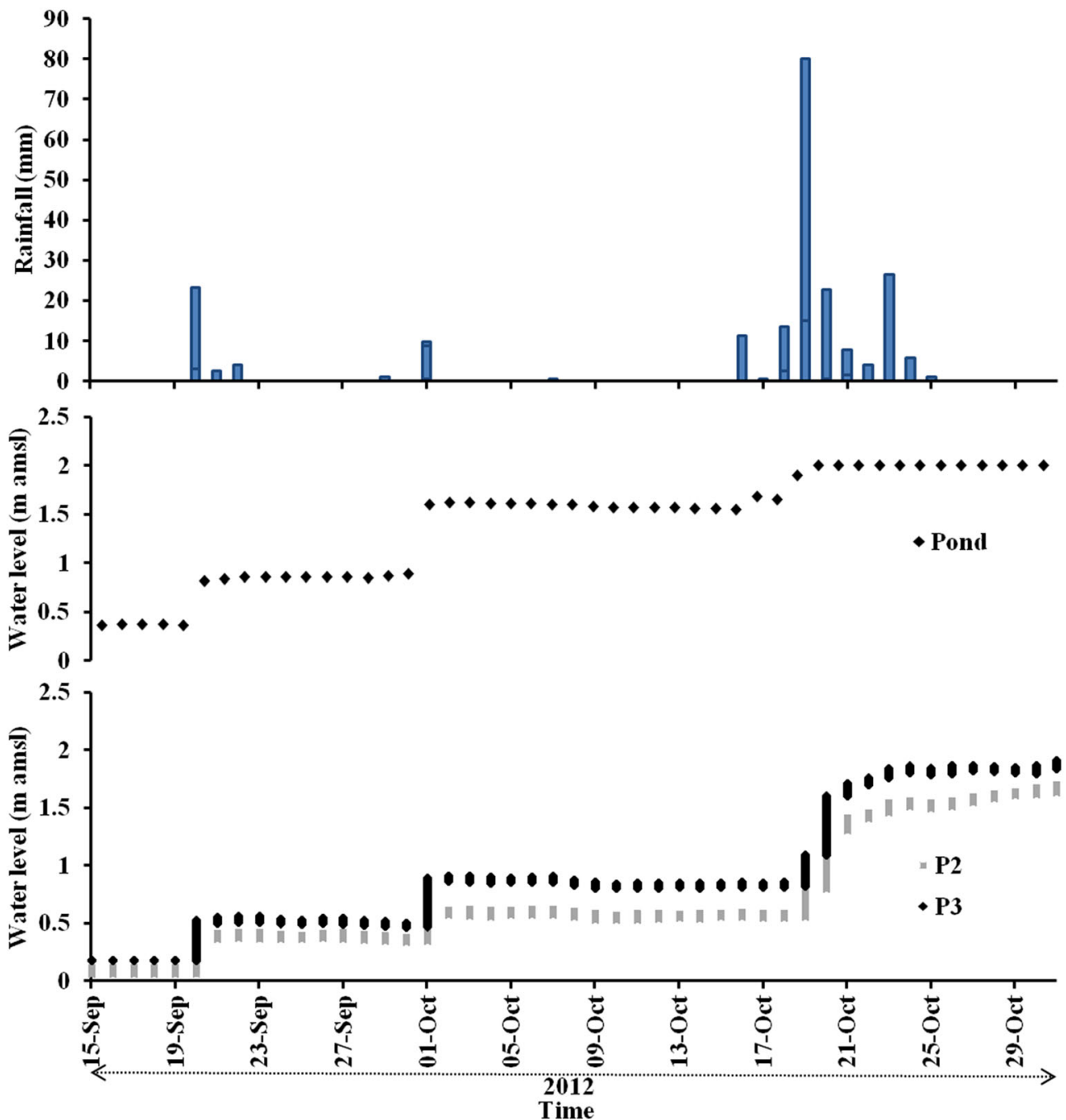

Figure 10. The 3-min interval water level response to pond water recharge in $\mathrm{P}_{2}$ and $\mathrm{P}_{3}$ during major rainfall event in 2012.

whereas that on the left side is conceptual due to the absence of piezometers on the west. The temporal variation in rainfall and water level in pond, $\mathrm{P}_{1}, \mathrm{P}_{2}$ and $\mathrm{P}_{3}$ for the period August 2012-May 2013 are shown in figure 9 . The closer temporal (3-min interval) water level response to the pond water recharge in the deeper piezometers $\mathrm{P}_{2}$ and $\mathrm{P}_{3}$ from September to October 2012 is shown in figure 10, which indicate that the groundwater level in $\mathrm{P}_{2}$ and $\mathrm{P}_{3}$ respond well with the pond water level. The water level in the pond is shallow from September 2012 to February 2013. As the rainfall was very low from November 2012 and the water level has started to reduce from January 2013, the pond became empty by the end of May 2013. The groundwater recharge was also calculated from the temporal variation in the water level in the pond and the regional pan evaporation data collected from India Meteorological Department.
A total amount of $98 \mathrm{~m}^{3}$ of water was recharged from September 2012 to May 2013.

\subsection{Improvement in groundwater quality}

The range of $\mathrm{EC}$ of water in pond, $\mathrm{P}_{1}, \mathrm{P}_{2}$ and $\mathrm{P}_{3}$ varies from 552 to $1778,555-2627,33,290-41,212$ and $58,313-73,640 \mu \mathrm{S} / \mathrm{cm}$, respectively (figure 11). This indicates that the quality of groundwater becomes poor with respect to depth and at a depth of $6 \mathrm{~m}$, groundwater is supersaline. The order of dominance of chemical ions in meq/l in the pond water and groundwater in $\mathrm{P}_{1}, \mathrm{P}_{2}, \mathrm{P}_{3}$ are as $\mathrm{Cl}^{-}>\mathrm{Na}^{+}>\mathrm{Mg}^{2+}>\mathrm{SO}_{4}^{2-}>\mathrm{Ca}^{2+}>\mathrm{HCO}_{3}^{-}$, $\mathrm{Cl}^{-}>\mathrm{Mg}^{2+}>\mathrm{Na}^{+}>\mathrm{Ca}^{2+}>\mathrm{SO}_{4}^{2-}>\mathrm{HCO}_{3}^{-}$, $\mathrm{Na}^{+}>\mathrm{Cl}^{-}>\mathrm{Mg}^{2+}>\mathrm{SO}_{4}^{2-}>\mathrm{Ca}^{2+}>\mathrm{HCO}_{3}^{-}$ and $\mathrm{Cl}^{-}>\mathrm{Na}^{+}>\mathrm{SO}_{4}^{2-}>\mathrm{Mg}^{2+}>\mathrm{Ca}^{2+}>$ $\mathrm{HCO}_{3}^{-}$, respectively. 

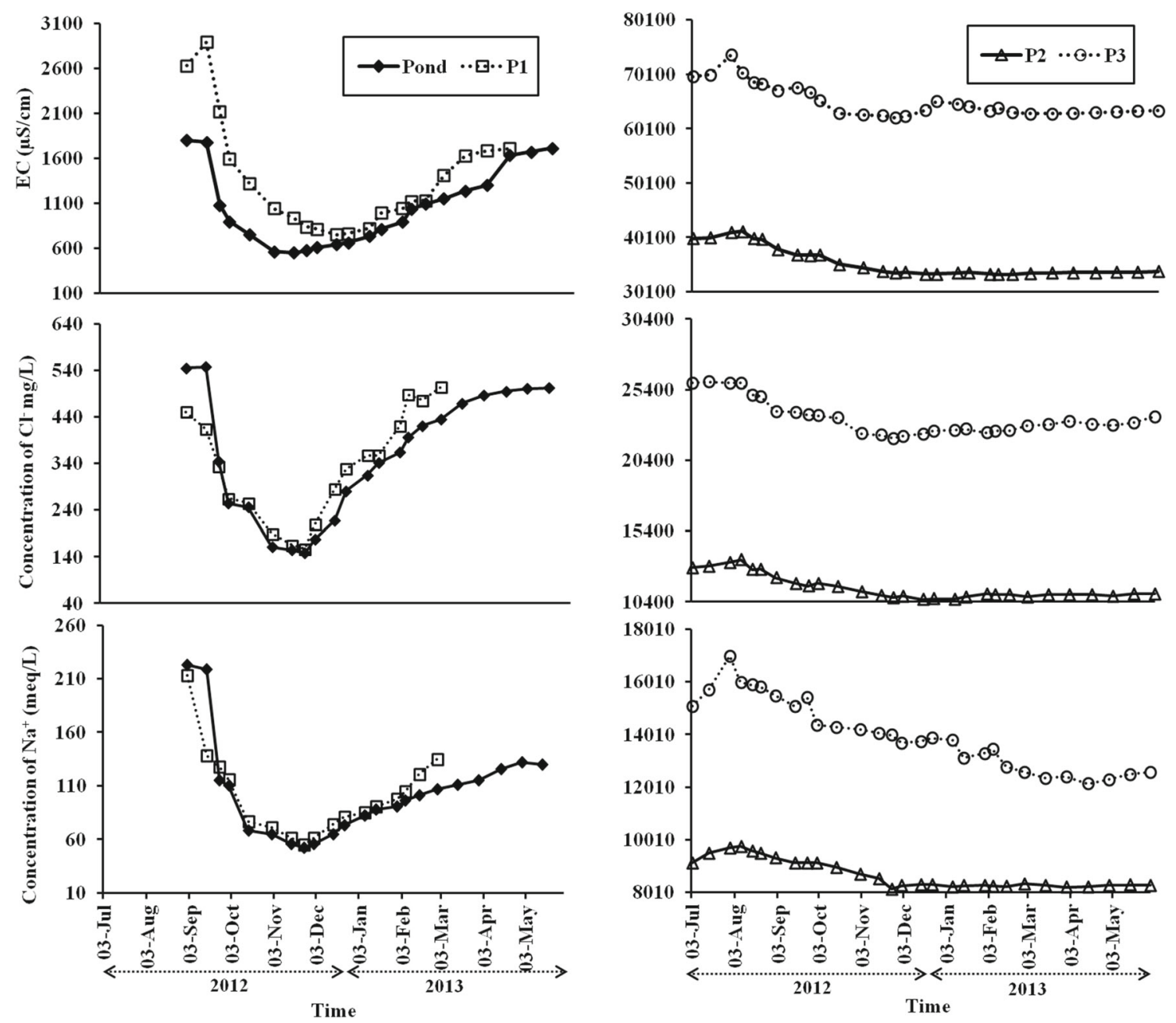

Figure 11. Temporal variation in EC, concentrations of $\mathrm{Cl}^{-}$and $\mathrm{Na}^{+}$of water from the pond and piezometers.

Schoeller diagram for the water samples collected from ponds, $\mathrm{P}_{1}, \mathrm{P}_{2}$ and $\mathrm{P}_{3}$ before filling up during rainfall and after drying up of the pond is shown in figure 12. Even though the ionic concentration of water in $\mathrm{P}_{2}$ and $\mathrm{P}_{3}$ show decreasing trend after the construction of the percolation pond, the concentration of major ions in $\mathrm{P}_{2}$ and $\mathrm{P}_{3}$ do not vary significantly before, during and after rainfall, as compared to pond $\mathrm{P}_{1}$. The reduction in concentration of major ions in water is due to the recharge of relatively fresh rain water collected in the pond. The comparatively slow rate of reduction in the ionic concentration in $\mathrm{P}_{2}$ and $\mathrm{P}_{3}$ is attributed to the very high salinity of water at greater depths in the study area. High concentration of major ions in groundwater may be due to the presence of marine sediments (UNDP 1987) and nearby saline surface water bodies in the area. As the groundwater in the area is brackish, the effect of dilution due to recharge of fresh water from the pond is not significant. The TDS in groundwater at $\mathrm{P}_{2}$ and $\mathrm{P}_{3}$ causes the fresh groundwater recharged from the pond with relatively low density to stay at the top of the saturated zone. The progressive increase in the concentration of ions with depth also indicates the effect of recharge from the pond.

As the top soil layers around the study area are of less permeable silt and clay, the direct rainfall recharge in the area will be very low. The very high EC of groundwater in this region due to the negligible rainfall recharge through the less permeable silt and clay surface layers was previously reported by Raicy and Elango (2014). The effect of recharge from the pond in improving the groundwater level and quality of water in the nearby area was also verified by comparing with the water level and EC in an open well which is not in the zone of influence of percolation pond. Considering that the geology and the rainfall is the same at the location of the percolation pond and the open well away 

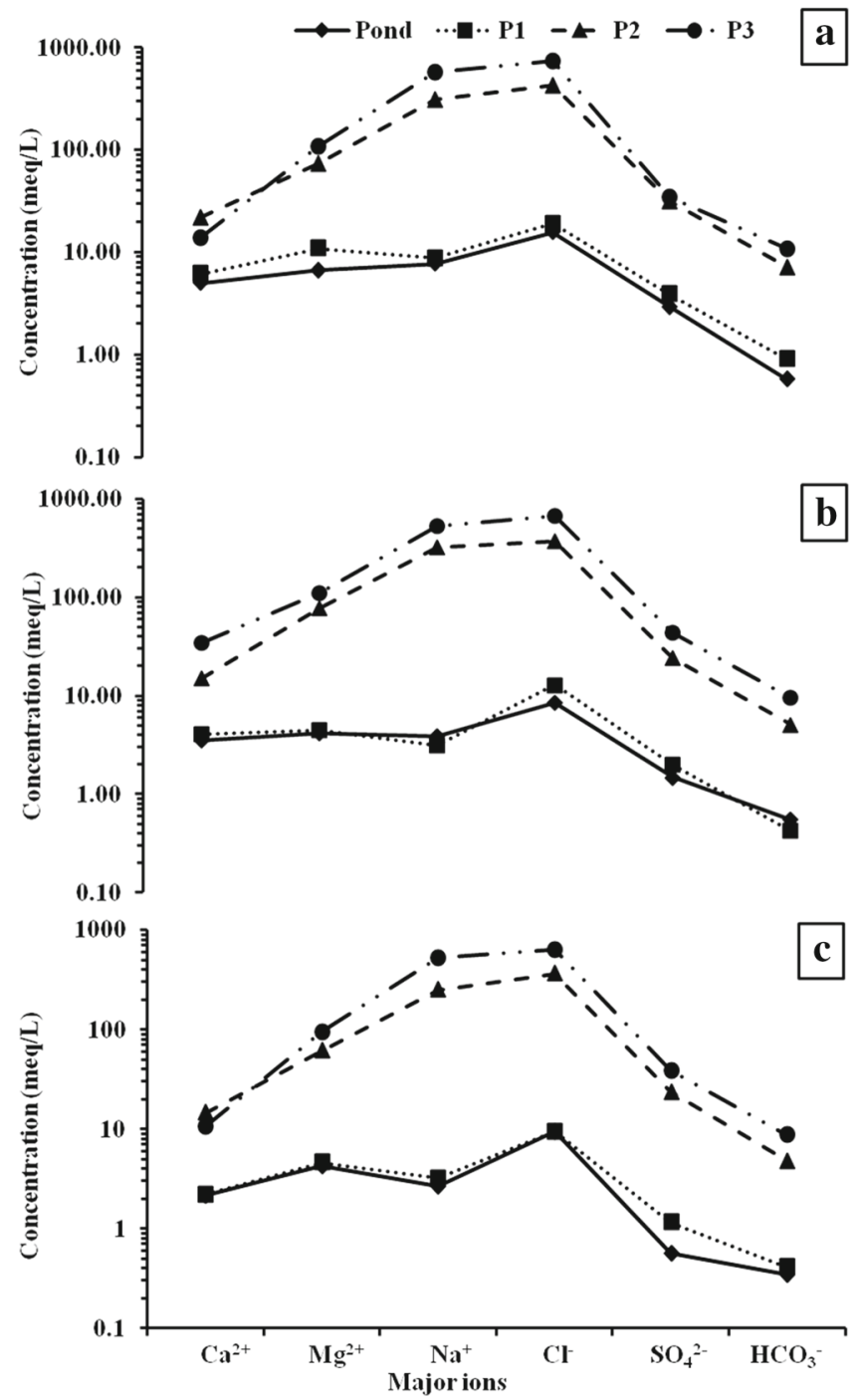

Figure 12. Schoeller diagram for the water samples collected from the pond and piezometers (a) before filling up of the pond, (b) during rainfall and (c) after drying up of the pond.

from the zone of influence of the pond, the rise in groundwater level was almost $1 \mathrm{~m}$ more in the piezometers located around the percolation pond than the open well (figure 13). This confirms that the rise in water level in piezometers close to the percolation pond is attributed to the effect of recharge of the pond. Also, the EC of groundwater in $\mathrm{P}_{1}$ which was $2627 \mu \mathrm{S} / \mathrm{cm}$ before filling of the pond has not increased beyond $1713 \mu \mathrm{S} / \mathrm{cm}$ even after the water level in the pond has lowered. Further the groundwater level in the open well during August 2012 and May 2013 were almost same, EC of groundwater was more during May 2013 as compared to that of August 2012 (figure 13). However, the EC of water in the open well also follows similar decreasing trend after rainfall recharge. This means that the reduced EC in piezometers close to pond even after drying up of the pond is attributed to the recharge from the percolation pond. Though the construction of pond could increase the volume of recharge and relatively improve the groundwater quality at shallow depth, no significant improvement in quality was observed in greater depths. This is attributed to very high salinity of groundwater beyond $5 \mathrm{~m}$ and the quantum of recharge is very less to dilute the water.

\subsection{Feasibility assessment}

It is important to assess the benefits of the construction of percolation pond in the study area. The total cost of construction and annual maintenance of the pond works out to be about Rupees 15000.00 (225 USD) and 5000.00 (300 USD) respectively and the volume of water recharged during the period of study is $98 \mathrm{~m}^{3}$. Considering the total cost 


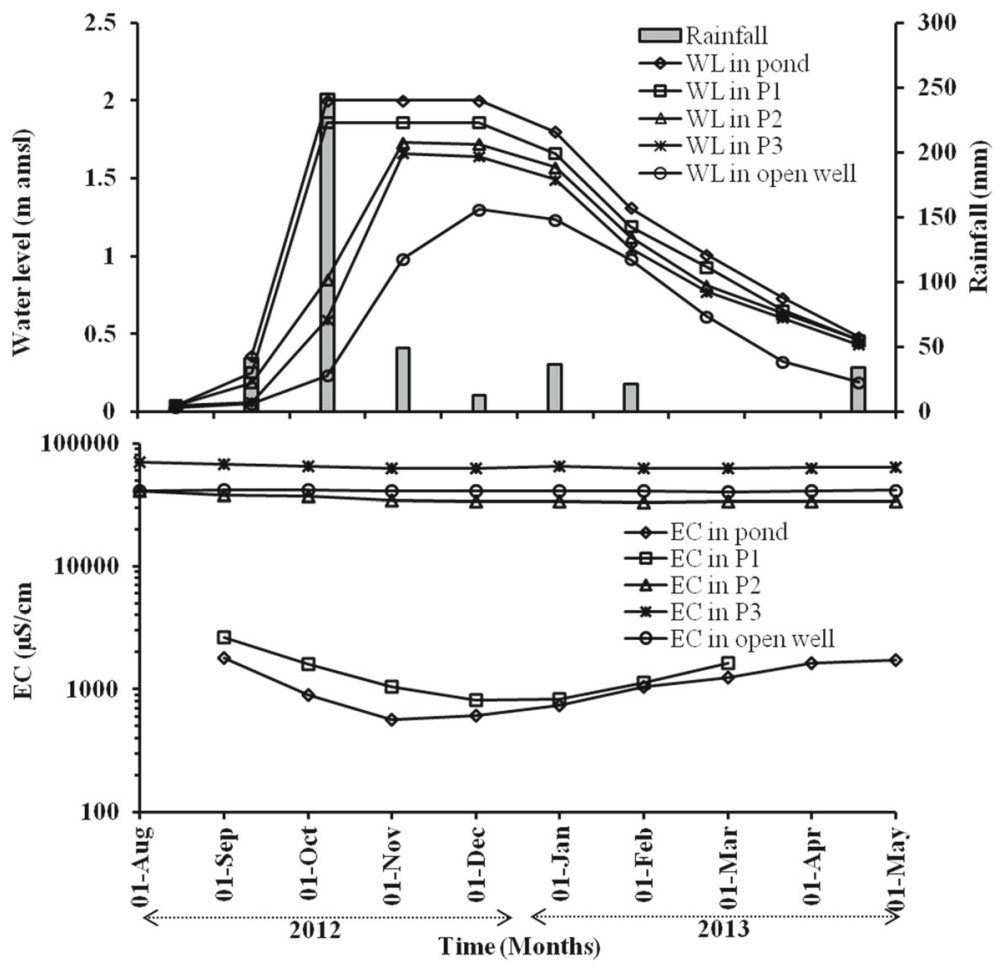

Figure 13. Comparison of groundwater level EC in observation well near the pond and away from the pond.

of construction and recurring expenditure for maintenance, the cost of water recharged from this pond works out to be about $0.225 \mathrm{Re} / \mathrm{l}$. Due to lower cost and ease in adoptability, percolation ponds are better option to improve the rainfall recharge in this area. However, the recharge of water from the pond could not bring considerable improvement in groundwater quality as the size of the pond is very small and the groundwater in the area is highly saline. The volume of water recharged by this pond is very low to significantly improve the groundwater quality in the area, however, the quality of groundwater could be improved if many such percolation ponds were constructed and maintained properly.

\subsection{Limitations and future considerations}

Percolation ponds are one of the simple and cost effective methods of MAR, which can also be adopted by farmers. Though construction of percolation ponds using MAR improves groundwater resources in overexploited aquifers, there are a number of limitations, which also needs to be emphasized. In order to get maximum benefit out of the MAR structures, it is vital to have a clear understanding of the aquifer characteristics to decide about the size and the type of structure.
Systematic maintenance of MAR structures is necessary to sustain their efficiency on a long term basis. The rainfall runoff coming into the pond also brings in considerable amount of sediments that get deposited at the bottom. This results in clogging of pores and thereby the rate of infiltration gets reduced over time. In the present study too, clogging of pores by finer sediments at the pond bottom was a major problem. Sediment layer of about $0.4 \mathrm{~m}$ thick was found deposited in the pond. Before the onset of monsoon during the subsequent year, this layer was manually scraped and excavated in order to achieve maximum recharge in the subsequent monsoon season. Hence, MAR structures need to be properly maintained by scrapping the clogging layers at least once a year, preferably before the commencement of monsoonal rains. Recharge shafts/wells, which are wells with slots both at the bottom and at the top may also be constructed inside the pond in such a way that the well is exposed above the bottom of the pond. In such cases, water will get directly recharged into the aquifer through the recharge well. Further the slotted portion above the pond may be wrapped with dhoti or saree to prevent the entry of suspended particles. If several such structures are constructed, the groundwater quality is expected to improve in a regional scale and enabling the provision of hand 
pumps can benefit the local people to pump atleast 150-200 litres of water per day with reasonable quality during the peak summer periods. Further, numerical groundwater modeling can be employed to simulate the impact of the recharge structure on the aquifer behaviour.

\section{Conclusions}

Selection of an appropriate location for the proper functioning of a MAR structure and the impact of the structure was investigated in a region north of Chennai, India. From the geophysical and lithological investigations, a suitable location was identified and study was carried out by constructing a pilot scale percolation pond. Due to the construction of a percolation pond, groundwater level has rised by about $30 \mathrm{~cm}$ and the quality of groundwater has improved. At the cost of about USD 225, a quantity of approximately $98 \mathrm{~m}^{3}$ of water could be recharged. Even though the quantity of water recharged from the pond is less, if several such ponds are constructed, the quality of water in this region is expected to improve in the upper part of the aquifer. This will enable the provision of hand pumps for the benefit of local community, who may get at least 150-200 l/day of water with reasonable quality during the peak summer period of MarchMay. Percolation ponds are found to be simple and economically feasible method for recharging the aquifer. This study indicated that a simple excavation without providing support for the slope and paving of the bunds helped to improve the groundwater level at the study site. This method can be easily adopted by farmers who can have a small pond within their farm to collect and store the rainwater. Cleaning of the pond needs to be done once a year by scrapping the accumulated sediments. As the dimension of the pond is small and the groundwater in the area is highly saline, considerable improvement in the groundwater quality could not be achieved at greater depths. However, ponds of larger size with several recharge shafts may help to improve the quality of water at greater depths.

\section{Acknowledgement}

Co-funding of this study under the 'Saph Pani' project of the European Commission within the Seventh Framework Program (Grant agreement no. 282911) is acknowledged.

\section{References}

Bartolino J R and Cunningham W L 2003 Ground-water depletion across the nation; U.S. Geol. Surv. Fact Sheet. 4 103-103.

Bird E C F 1969 Coasts; MIT Press, Cambridge, 246p.

Bristow C S 2000 Ground penetrating radar in aeolian dune sands; In: Ground penetrating radar theory and applications (ed.) Jol H M, Elsevier Science, Amsterdam, pp. 273-297.

Bristow C S, Bailey S D and Lancaster N 2000 The sedimentary structure of linear dunes; Nature 406 56-59.

Calvache M L, Duque C, Gomez F J M and Crespo F 2011 Processes affecting groundwater temperature patterns in a coastal aquifer; Int. J. Environ. Sci. Tech. 8 223-236.

Central Ground Water Board 2005 Master plan for artificial recharge to groundwater in India; Ministry of Water Resources, Government of India.

Charalambous A N and Garratte P 2011 Rechargeabstraction relationships and sustainable yield in the Arani-Kortalaiyar groundwater basin, India; Q. J. Eng. Geol. Hydrogeol. 42 39-50.

Choudhury K, Saha D K and Chakraborty P 2001 Geophysical study for saline water intrusion in a coastal alluvial terrain; J. Appl. Geophys. 46 189-200.

Chowdhury A, Jha M K and Chowdary V M 2010 Deliniation of groundwater recharge zones and identification of artificial recharge sites in West Medinipur district, West Bengal using RS, GIS and MCDM techniques; Environ. Earth Sci. 59 1209-1222.

Daniels D J, Gunton D J and Scott H E 1988 Introduction to subsurface radar; IEE (Institution of Electrical Engineers) Proceedings 135 278-320.

Deshraj T, Raicy M C, Devi K, Devender K, Ilya B, Srinivasan P, Nagesh R I, Guin R, Sengupta D and Rajesh R Nair 2012 Sediment characteristics of tidal deposits at Mandvi Gulf of Kuchchh, Gujarat, India. Geophysical textural and mineralogical attributes; Int. J. Geosci. 3 515-524.

Dwarakanath C T, Rayner E T, Mann G E and Dollear F G 1968 Reduction of aflatoxin levels in cotton seed and peanut meals by ozonation; J. Amer. Oil Chem. Soc. 45 93-95.

EKKO_View 2 User's guide for ground penetrating radar viewing software, copyright 2008 Sensors \& Softwares Inc.

Elango L and Manickam S 1987 Hydrogeochemistry of the Madras aquifer India. Spatial and temporal variation in chemical quality of groundwater; Geol. Soc. Hong Kong Bull. 3 525-534.

Elango L and Ramachandran S 1991 Major ion correlations in groundwater of a coastal aquifer; J. Indian Water Resour. Soc., pp. 54-57.

Farrington J, Turton C and James A J 1995 Participatory Watershed Development: Challenges for the Twenty-First Century (New Delhi: OUP).

Hashemi H, Berndtsson R, Kompani-Zare M and Persson M 2013 Natural vs. artificial groundwater recharge, quantification through Inverse Modeling; Hydrol. Earth Syst. Sci. 17 637-650, doi: 10.5194/hess-17-637-2013.

Hertig A W and Glesson T 2012 Regional strategies for accelerating global problem of groundwater depletion; Nature Geosci. 5 853-861. 
Huntington T G 2008 Can we dismiss the effect of changes in land-based water storage on sea-level rise?; Hydrol. Process. 22 717-723.

Indu S Nair 2016 Assessment of seawater intrusion in an alluvial aquifer by hydrochemical-isotopic signatures and geochemical modelling; unpublished $\mathrm{PhD}$ thesis, Anna University, Chennai, Tamil Nadu.

IX1D v2 version 1.0. Exploring IX1D The Terrain Conductivity/Resistivity Modelling Software; copyright 2008 Interplex Ltd.

Kaufman A A and Hoekstra P 2001 Electromagnetic Soundings; Elsevier, Amsterdam.

Kearey P, Brooks M and Hill I 2002 An introduction to geophysical exploration; Blackwell Science Publishers.

Konikow L F and Kendy E 2005 Groundwater depletion: A global problem; Hydrogeol. J. 13 317-320.

Malvern master sizer user's manual 2000, Malvern Instruments Limited.

Mohammadi K 2008 Practical Hydroinformatics. Water Science and Technology Library; Springer Verlag, Berlin, pp. $127-138$.

Neal A and Roberts C L 2000 Application of Ground Penetrating Radar (GPR) to sedimentological geomorphological and geoarchaeological studies in coastal environments In: Coastal and estuarine environments: Sedimentology, geomorphology and geoarchaeology (eds) Pye K et al., Geol. Soc. Spec. Publ. 175 139-171.

Raicy M C and Elango L 2014 An integrated approach to understand the lake water groundwater interaction in coastal part of Arani-Koratalaiyar River basin, Tamil Nadu, India; Disaster Adv. 7 32-38.

Paniconi C, Khlaifi I, Giuditta L, Andrea G and Jamila T 2001 Modeling and analysis of seawater intrusion in the coastal aquifer of Eastern Cap-Bon, Tunisia; 43, Transport in porous media, pp. 3-28.

Parimala R S and Elango L 2013 Impact of recharge from a check dam on groundwater quality and assessment of suitability for drinking and irrigation purposes; Arab. J. Geosci. 7 3119-3129.

Raicy M C, Parimalarenganayaki S, Schneider M and Elango L 2014 Groundwater responses to managed aquifer recharge structures: Case studies from Chennai, Tamil Nadu, India; In: Natural Water Treatment Systems for
Safe and Sustainable Water Supply in the Indian Context (eds) Wintgens T, Nattorp A, Elango L and Asolekar S R, Chapter 5, IWA Publishing, pp. 99-112.

Rajaveni S P, Indu S N and Elango L 2015 Finite element modelling of a heavily exploited coastal aquifer to assess the response of groundwater level to the changes in pumping and rainfall variation due to climate change; Hydrol. Res., doi: 10.2166/nh.2015.211.

Rao N J 1979 Studies on the Quaternary formations of the coastal plains flanking Pulicat lake; Geol. Surv. India Misc. Publ. 45 231-233.

Rostami S, Nakhaei M and Khodaei K 2010 The Effect of Artificial Recharge on Groundwater Potential in Gharve Plain, Kurdistan; The 1st National Conference on Applied Research of Iran Water Resources, Kermanshah.

Russo T A, Fisher A T and Lockwood B S 2014 Assessment of managed aquifer recharge site suitability using GIS and modeling; Groundwater 53 389-400.

Schwartz F W and Ibaraki M 2011 Groundwater: A resource in decline; Elements 7 175-179.

Shammas M I and Jacks G 2008 Seawater intrusion in the Salalah plain aquifer, Oman; Environ. Geol. 53 575-587.

Sundaram V L K, Dinesh G, Ravikumar G and Govindaraju D 2008 Vulnerability assessment of seawater intrusion and effect of artificial recharge in Pondicherry coastal region using GIS; Ind. J. Sci. Tech. 7 1-7.

United Nations Development Program 1987 Hydrogeological and artificial recharge studies, Madras, Technical report, United Nations Department of technical co-operation for development, New York, USA.

Van H S, FitzGerald D M, Mckinlay P A and Buynevich I V 1998 Radar facies of paraglacial barrier systems: Coastal New England, USA; Sedimentology 45 181-200.

Werner A 2001 Managing Saltwater Intrusion in the Pioneer Valley, Northern Queensland, Australia: Modelling Strategies, Preliminary Results and Future Challenges; First International Conference on Saltwater Intrusion and Coastal Aquifers - Monitoring, Modeling, and Management, Essaouira, Morocco.

Western A W, Bloschlb G and Grayson R B 1998 Geostatistical characterization of soil moisture patterns in the Tarrawarra catchment; J. Hydrol. 205 20-37.

www.epa.gov/esd/cmb/pdf/JAG-TDSpublished.pdf. 